\title{
Evaluation of attitudes of university students for handicapped individuals
}

\author{
Zekiye Özkan ${ }^{1 \mathrm{a}}$, Mustafa Atl1 ${ }^{1}$, and Ersin Arslan ${ }^{1}$ \\ ${ }^{1}$ School of Physical Education and Sports, Yuzuncu Yil University, 65040 Van, Turkey
}

\begin{abstract}
Education has an important role in humans' behaviours. Undergraduate education has headed among factors that influence maturation period before vocational lifes of individuals. The purpose of this study is to determine whether attitudes of university students for handicapped individuals differ according to some variables. This study which was carried out in screening model was done with 1167 people including 646 females 521 males who maintain their education at faculties taking initial teacher training in 2016 spring term at Yuzuncu Yil University. As data collection tool, Attitude Scale for Being Educated of Handicapped Individuals and Personal Information Form, which was developed by Kosterilioglu [12], was used. As statistical method, Duncan's multiple range test was used in determining different groups following one-wat analysis of variance. Among these variables, pearson coefficients of correlation were calculated separately in groups in determining relation. In determining relationship between groups and categorical variables, chi square test was used. In calculations, value of $p$ was taken as 0,05 and SPSS statistic program was used for calculations. While point average of attitudes of male students, who maintain their educations at Yuzuncu Yil University, for handicapped people was ascertained as $54.27 \pm 23.54$, point average of attitudes of female students was determined as $55.86 \pm 26.34$. A significant difference between male and female students according to gender variable was not seen in attitudes for being educated of handicapped individuals $(\mathrm{P}>0,05)$. It was observed that attitudes for being educated of handicapped individuals in starting and end of undergraduate term were higher than intermediate classes $(\mathrm{P}<0,01)$. Although a significant difference in kind of high schools from which students graduated was not seen, attitudes of graduates from science and sport high schools were found higher than graduates from other high schools. Those of students who has low and intermediate academic success were found more significant and different than those of students who has high success. $(\mathrm{P}<0,01)$. Whereas a significant difference between students, who took lessons related to education of handicappeds and the students who did not take those lessons during education period was not seen, attitudes of those who took the lesson were found higher. A significant difference was found in attitudes of those who took Handicapped and Sport lecture among
\end{abstract}

${ }^{a}$ Corresponding author: zekiyeozkan06@hotmail.com 
lessons learned in comparison to those who took other lectures $(\mathrm{P}<0,01)$. Attitudes of those who do not use social media were found more significant and higher $(\mathrm{P}<0,05)$. It is thought that addition of practice along with theoretical lectures for individuals with special needs during university education and including public service ads related to handicappeds in social media will make a significant contribution to vocational experiences of teacher candidates.

Keywords: Attitudes for Handicapped, Sport, Academic Success

\section{Introduction}

Training activities carried out for handicapped have become important in recent years. They have become quite effective in educations of individuals with special needs thanks to growth of sensitiveness towards the handicapped at government policy and provided facilities. Accumulations gained during university education have become effective in Professional competency.

Educations of handicapped children in Turkey have been secured with laws especially Constitution [18]. Students with special needs need to have an intense training by starting from early childhood and being suited for their needs. Education and training services offered to individuals with special needs in our country are becoming different day-by-day, and in the direction of this differentiation, they are flourishing. Individuals with special needs have participated in training activities at special training classes, at business college and in inclusive environment with their peers showing normal development [20]. When field definition is examined at the Ministry of Education's regulations for special training services, special training is defined as the education which is maintained suitable environments resting on personnels trained peculiarly for meeting education and social needs of individuals with special needs, features of individuals with special needs in all areas of development with enhanced training programmes and methods and sufficiencies of individuals with special needs in the academic disciplinary fields [17]. According to definitions of World Health Organisation, disability is a status in which roles expected from person are restricted or are not performed due to a defect or handicap based on age, gender, social and cultural factors [2]. Individuals who have needs in terms of education experiences are in need of individualized education programs for maximisation of their education performances [19]. In the environment in which we live, the most fundamental and permanent barriers in front of handicapped and disability are attitudes created and lived in social extent.

Attitude functions as protector of self like a defence mechanism. In other words, It has structure that protects personality of individual and is supposed to prevent any threats against his/her basic values. Therefore, naturally, individual tends to develop the attitudes protecting his/her personality. Individual can develop the attitudes providing for expressing himsef/herself in terms of self-values and perceiving as he/she wants to see. Attitudes doing this duty complete self identity of individual and can strengthen it [11]. In undergraduate education period, development of our attitudes healthily and positively has an important position in terms of professional competency. Acquirements that teacher candidates gain during education not only contribute to professional competency and also increase education quality of disadvantageous groups.

One of the occupational groups having an important position in formation of these attitudes is teachership. Attitudes of teachers have effects on handicapped individuals attitudes that occur between childhood and maturity of individuals and then they carry to 
work lifen [14]. Attitudes of individuals working at educational institutions are seen important in this point.

\section{Method}

\subsection{The purpose of the study}

The purpose of this study is to research attitudes of teacher candidates, who took lessons related to education of handicappeds and who did not take those lessons during education period, for education of handicapped individuals

\subsection{The problem of the study}

The purpose of this study is to determine whether attitudes of teacher candidates, who took lessons related to education of handicappeds and who did not take those lessons during education period, for education of handicapped individuals change according to some demographical variables or not.

\subsection{Data collection tool}

As data collection tool, Attitude Scale for Being Educated of Handicapped Individuals and Personal Information Form, which was developed by Kosterilioglu [12], was used.

\subsection{Participants}

This study which was carried out in screening model was done with 1167 people including 646 females 521 males who maintain their education at faculties taking initial teacher training in 2016 spring term at Yuzuncu Yil University.

\subsection{Statistical analysis}

As statistical method, Duncan's multiple range test was used in determining different groups following one-way analysis of variance. Among these variables, pearson coefficients of correlation were calculated separately in groups in determining relation. In determining relationship between groups and categorical variables, chi square test was used. In calculations, value of $\mathrm{p}$ was taken as 0,05 and SPSS statistic program was used for calculations.

\section{Findings and interpretation}

The purpose of this study is to try to determine attitudes of teacher candidates, who took lessons related to education of handicappeds and who did not take those lessons during education period, for education of handicapped individuals according to some demographical variables

Table 1. Gender

\begin{tabular}{|c|c|c|}
\hline Gender of Variables & $\mathbf{X} \pm$ SD & P \\
\hline Male & $54.27 \pm 23.54$ & \multirow{2}{*}{0,282} \\
\hline Female & $55.86 \pm 26.34$ & \\
\hline
\end{tabular}


A significant difference between male and female students according to gender variable was not seen in attitudes for being educated of handicapped individuals $(\mathrm{P}>0,05)$.

Table 2. Academic success and attitude points for being educated of handicapped individuals

\begin{tabular}{|c|c|c|}
\hline Academic Success & $\mathbf{X} \pm$ SD & P \\
\hline Low & $57.34 \pm 22.75 \mathrm{a}$ & \multirow{2}{*}{$\mathbf{0 . 0 0 1}^{*}$} \\
\hline Intermediate & $57.01 \pm 22.75 \mathrm{a}$ & \\
\hline High & $50.71 \pm 25.13 \mathrm{~b}$ & \\
\hline
\end{tabular}

Those of students who has low and intermediate academic success were found more significant and different that those of students who has high success. $(\mathrm{P}<0,01)$.

Table 3. Grades

\begin{tabular}{|c|c|c|}
\hline Grades & $\mathbf{X} \pm$ SD & P \\
\hline 1st Grade & $58.76 \pm 25.91$ & \\
\hline 2nd Grade & $46.48 \pm 22.95$ & \multirow{2}{*}{$\mathbf{0 . 0 0 1}^{*}$} \\
\hline 3rd Grade & $55.59 \pm 24.57$ & \\
\hline Grade(4th Grade) & $58.03 \pm 25.13$ & \\
\hline
\end{tabular}

It was found that attitudes for being educated of handicapped individuals in starting and end of undergraduate term were more significant and different intermediate classes $(\mathrm{P}<0,01)$.

Table 4. Name of lecture

\begin{tabular}{|c|c|c|}
\hline Name of lecture & $\mathbf{X} \pm$ SD & P \\
\hline Handicapped and Sport & $71.11 \pm 18.86 \mathrm{a}$ & \multirow{2}{*}{} \\
\cline { 1 - 2 } Special Training & $52.62 \pm 24.93 \mathrm{~b}$ & \multirow{2}{*}{.001 $^{*}$} \\
\hline Others & $48.15 \pm 26.05 \mathrm{~b}$ & \\
\hline Not taken & $54.37 \pm 25.17 \mathrm{~b}$ & \\
\hline
\end{tabular}

Whereas a significant difference between students, who took lessons related to education of handicappeds and the students who did not take those lessons during education period was not seen, attitudes of those who took the Handicapped and Sport lesson were found more significant and different. $(\mathrm{P}<0,01)$.

Table 5. Reading habit

\begin{tabular}{|c|c|c|}
\hline Reading Habit & $\mathbf{X} \pm$ SD & P \\
\hline Yes & $55.34 \pm 25.83$ & \multirow{2}{*}{0.300} \\
\hline No & $57.05 \pm 22.50$ & \multirow{2}{*}{0.300} \\
\hline Sometimes & $53.79 \pm 25.47$ & \\
\hline
\end{tabular}

Significant difference was not seen statistically $(\mathrm{P}>0,05)$.

Table 6. Following social media

\begin{tabular}{|c|c|c|}
\hline Following social media & $\mathbf{X} \pm$ SD & P \\
\hline Yes & $55.44 \pm 25.60 \mathrm{ab}$ & \multirow{2}{*}{$\mathbf{0 . 3 6}^{*}$} \\
\hline No & $59.48 \pm 20.96 \mathrm{a}$ & \multirow{2}{*}{} \\
\hline Sometimes & $52.71 \pm 25.36 \mathrm{~b}$ & \\
\hline
\end{tabular}

Attitudes of those who do not use social media were found more significant and higher $(\mathrm{P}<0,05)$. 


\section{Results and discussion}

Education of individuals with special needs is among the important issues that developing societies have dwelled on recently.

Special Training lecture is critical for teacher candidates who have undergraduate training at faculties of educations' departments that train teachers out of special training field. Teacher candidates will definitely come across with special students during teaching professions.

Along with increasing of importance given education and training activities, special training gains importance. Students with special needs need to have an intense training by starting from early childhood and being suited for their needs [20].

In our study, whereas a significant difference between students, who took lessons related to education of handicappeds and the students who did not take those lessons during education period was not seen, attitudes of those who took the lesson were found higher. Average of those who took lesson was determined as $56.03 \pm 24$ and average of those who did not take lessons was ascertained as $54.47 \pm 25.28$. It supports our result that we found at literature research [22]. Contrary to our study, there are literature studies which state that attitudes of participants were found positive [1, 5, 7, 8, 9, 11]. Alptekin and Bat1k [16] determined that Special Training lecture affected attitudes of 1st grade students at Deaf or Hard of Hearing Teaching for individuals, who were affected from inadequacy, in a positive way. Melekoglu [13] stated that as result of the study, teacher candidates' acquisition positive attitudes for individuals with special needs and their awareness was positive. Sar1 and Bozgeyik [11] point out that generally, teacher candidates who do not take special training lecture have rather negative opinions for handicapped children.

İzci [6] suggests that information and abilities of class teacher candidates about special training and inclusive education are not enough.

Durdukoca [21] points out that teacher candidates who have enough practicums will make important contributions to successfully implementation of programs, which will be prepared for students needing special training, in their work lifes. Tortop et. al. [10] assert that there are differences and mistakes in teacher candidates perception related to "mentally handicapped individual" term due to lack of information of teacher candidates about mentally handicapped individuals and education of mentally handicapped individuals.

It is stated that detailed traineeship of teachers, who change and develop society positively, about disability, being hired of people who are expert about this issue and being performed of regularly information sharing for students about disability can influence attitudes for disability positively [14].

In our study, while point average of males was ascertained as $54.27 \pm 23.54$, point average of females was found $55.86 \pm 26.34$. A significant difference between male and female students according to gender variable was not seen in attitudes for being educated of handicapped individuals $(\mathrm{P}>0,05)$. In the studies which were carried out with different sample groups within the scope of special training in literature, it is seen that gender variable is not influential in attitude points $[3,4,5,9,11,14,15]$.

In our study, although a significant difference in kind of high schools from which students graduated was not seen, attitudes of graduates from science and sport high schools were found higher than graduates from other high schools. In the study done in this field, it is pointed out that difference in attitudes of participants for handicapped individuals according to kind of high school from which they graduated was not seen [8, 14].

In our study, it was determined that reading habit did not affect attitude points $(\mathrm{P}>0,05)$. Attitudes of students against handicapped individuals according to following publication state that there is no significant difference in scale extents [8]. 
Attitude points of students who has low and intermediate academic success were found more significant and different than those of students who has high success $(\mathrm{P}<0,01)$. In another study that was done in literature, it is asserted that a significant difference in attitudes for inclusive education according to academic success variables was not found [15].

In our study, it was observed that there was no significant difference between those who have handicapped individual in their family and those who do not. While supporting our study $[3,4,11,22]$, a different study states that a significant difference was seen on behalf of teachers candidates who do not have handicapped individual in their environment [15].

Colak and Cetin [14] point out that sense of disability of those who have handicapped individual in their family is higher.

In our study, it was observed that attitudes for being educated of handicapped individuals in starting and end of undergraduate term were higher than intermediate classes $(\mathrm{P}<0,01)$. Attitudes of students who do not follow social media were found more significant and higher $(\mathrm{P}<0,05)$.

In consequence of the study, that attitude points of those who do not follow social media are high was examined as thought-provoking. Experience and practice is an important issue in teaching profession. It can be said that being taught of lessons related to special training during undergraduate education theoretically is not enough to increase awareness. Evaluation of lessons with practice and theoretical extent during undergraduate education will ease orientating of teacher candidates to the profession, and also will make positive contributions to education of individuals showing normal development as well as individuals with special needs.

\section{References}

1. A. Örel, G. Toret, Z. Zerey, Ankara University Faculty of Educational Sciences Journal of Special Education , 5, 1 (2004)

2. $\quad$ D. S. Özer, Engelliler için beden eğitimi ve spor. Nobel.4th press. (2013)

3. D. Yaral1, Erzincan University Journal of Faculty of Educational Sciences, 17, 2 (2015).

4. D. Yaral1, Pamukkale University Journal of Institute of Social Sciences, 24, (2016).

5. E. Altıntaş, S. Şengül, e-Kafkas Educational Research Journal, 1, 3 (2014)

6. E. İzci, Electronic Journal of Social Sciences, 4, 14 (2005).

7. F. Gürsel, Hacettepe University Journal of Faculty of Education, 31(2006)

8. F. Şahin, B. Güldenoğlu, Amasya University Journal of Faculty of Education, 2; 1 (2013)

9. H. Bek, H. Gülveren, A. Başer, Uşak University Journal of Social Sciences, 2, 2 (2009)

10. H. S. Tortop, B. Kandemir, Ö. E. Kaya, F. Demir, Abant İzzet Baysal University Journal of Faculty of Education, 15, (2015)

11. H. Sarı, H. Bozgeyik, Selçuk University Journal of Institute of Social Sciences, 9, 183-204 (2003).

12. İ. Kösterelioglu, Ahi Evran University Journal of Faculty of Education, 14, 3 (2013)

13. M. A. Melekoglu, Theory and Educational Sciences, 13, 2 (2013)

14. M. Çolak, C. Çetin, C. Dokuz Eylül Univeristy Journal of Faculty of Economics and Administrative Sciences, 29, 1 (2014).

15. N. Göçmen. M. Bozkurt, M.Ç Aydın. e-Kafkas Educational Research Journal, 4, 1 (2017).

16. S. Alptekin, M. V. Batık, International Journal of Educational Research, 4, 4 (2013) 
17. S. Çuhadar, Özel Eğitim Süreci. S. Vuran (Ed.), Özel Eğitim içinde (p 7). Ankara: Maya Academy. (2013).

18. S. Eripek, Ankara University Faculty of Educational Sciences Journal of Special Education, 5, 2 (2004)

19. S. Şahin, H. Yaban, E. Acar, B. Dönmez (Ed.), Özel Gereksinimli Çocuklar ve Özel Eğitim içinde (p.71). Ankara: Eğiten Kitap. (2011).

20. S. Talas, F. Kaya, N. Yıldırım, L. Yazıc1, H. Nural et. al. Journal of European Education, 6, 3, 31-42. (2016).

21. Ş. F. Durdukoca, International Periodical for the Languages, Literature and History of Turkish or Turkic, 10, 11 (2015)

22. Z. F. Temel, Hacettepe University Journal of Faculty of Education, 18, (2000) 